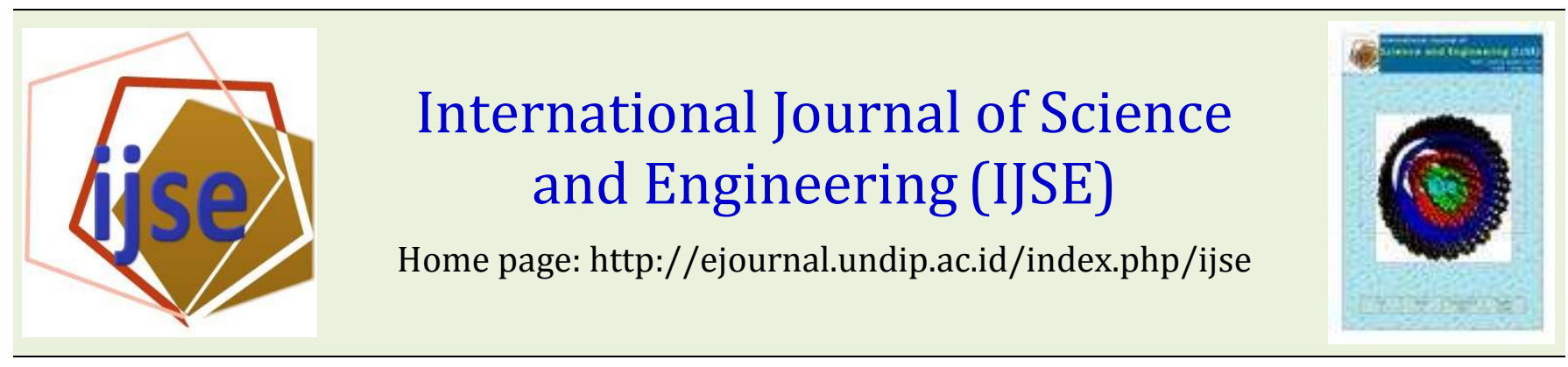

\title{
Taro Tube Flour Modification via Hydrogen Peroxide Oxidation
}

\author{
Catarina Sri Budiyati, Dessy Ariyanti \\ Department of Chemical Engineering, Engineering Faculty, Universitas Diponegoro, Indonesia \\ e-mail: wp.dessy@gmail.com
}

\begin{abstract}
Colocasia esculentum (L) Schott known as "Talas bogor" in Indonesian language is easily grown in every island in Indonesia. It proved to have high content of carbohydrate as it can be utilize for wheat flour replacement in addition to prior modification using hydrogen peroxide. The objective of this research was to improve the quality of taro flour by assessing the effect of several parameter such as ratio of slurry, oxidation agent concentration, oxidation time and temperature. The result shows that using ratio of slurry $20 \%$ with $2 \%$ of $\mathrm{H}_{2} \mathrm{O}_{2}$ concentration in temperature of oxidation process $30^{\circ} \mathrm{C}$ and 60 min operation time can produced good quality of modified taro tube flour in terms of swelling power and water solubility with $7.2 \mathrm{~g} / \mathrm{g}$ and $6.93 \%$ respectively. This condition has chosen by taking the technical and economic feasibility as consideration. This result also can be used as proof of evidence that using $\mathrm{H}_{2} \mathrm{O}_{2}$ as an oxidizing agent in the process of taro tube flour modification can improve the functional properties of the flour. As the swelling power and water solubility of original taro tube flour were $3.7 \mathrm{~g} / \mathrm{g}$ and $1.8 \%$ respectively.
\end{abstract} Keywords: hydrogen peroxide, flour modification, swelling power, water solubility

Submission: 10 August 2014

Corrected : 15 September 2014

Accepted: 5 October 2014

Doi: 10.12777 /ijse.7.2.137-142

[How to cite this article: Budiyati, C.S. and Ariyanti, D.. (2014). Taro Tube Flour Modification via Hydrogen Peroxide Oxidation. International Journal of Science and Engineering, 7(2),137-142, Doi: 10.12777/ijse.7.2.137-142

\section{Introduction}

As one of the largest tropical country, Indonesia has abundant species of carbohydrate source plantation. Among all, some are known as edible starchy tuberous root which can be found extensively in various form such as cassava, potatoes, sweet potatoes, and tuber. Colocasia esculentum (L) Schott known as "Talas bogor" in Indonesian language is easily grown in every island in Indonesia. It proved to have high content of carbohydrate as it can be utilize for wheat flour replacement in addition to prior chemical and physical modification. In addition to high carbohydrate content, taro tube also proved to have tiny starch particle characteristic $(1-5 \mu \mathrm{m})$ and rich of amylose content (20-25\%) which make taro tube easily to digest by small favor of $\alpha$-amylase enzyme to become glucose monomer (Agama-Acevedo et al., 2011). It is a recommended foodstuff for adults who experience indigestion problem as it also contain small amount of protein, vitamin $\mathrm{C}$, riboflavin, niasin and mineral (Niba, 2003). Colocasia esculentum (L) Schott based food product need to be develop further in order to increase its properties and functionality as it is utilize as wheat flour replacement.

Taro flour produced from conventional preparation (grinding of oxalate free sliced dried taro tube) are saved for human consumption. However, this taro flour still has major drawbacks such as low swelling power and water solubility. In order to fix the flaws, taro flour needs further processing such as chemical modification which has ability to increase its physical-chemical properties. Chemical modification such as oxidation technique using $\mathrm{H}_{2} \mathrm{O}_{2}$ as oxidizing agent and $\mathrm{CuSO}_{4} \cdot 5 \mathrm{H}_{2} \mathrm{O}$ as catalyst has proven to become one method that can increase taro tube flour chemical properties. As stated in Ariyanti 2013, those increment were not followed by the physical properties such as color and taste. Based on that, further research needs to be done to find out the optimum condition of modification process through oxidation technique without using catalyst as this catalyst was the suspect of the source of unwanted color and taste. The objective of this research was to improve the quality of taro flour by assessing the effect of several parameter such as ratio of slurry, oxidation agent concentration, oxidation time and temperature of oxidation process using $\mathrm{H}_{2} \mathrm{O}_{2}$ as oxidizing agent as suggest by Alam \& Hasnain (2008). $\mathrm{H}_{2} \mathrm{O}_{2}$ was chosen as oxidizing agent as its availability, easy to handle and non-toxic for the environment. 


\section{Materials and Methods}

\subsection{Materials}

Taro tube (Colocasia esculenta (L) Schott) were bought from local market in Salatiga, Indonesia. The flour were obtained by conventional preparation such as slicing, drying and grinding as the characteristic can be found in Table 1. Demineralized water were obtained from Reverse Osmosis unit in Department of Chemical Engineering, Universitas Diponegoro. Other pro-analyst chemical reagent were bought from Sigma-Aldrich Co. Inc. in Semarang, Indonesia.

Table 1. Taro tube flour characteristic

\begin{tabular}{lc}
\hline Parameter & Value \\
\hline Water content (\%) & 11,289 \\
Carbohydrates (\%) & 78,477 \\
Protein (\%) & 5,323 \\
Fat (\%) & 0,084 \\
Ash (\%) & 4,827 \\
\hline
\end{tabular}

\subsection{0xidation process}

Taro tube flour were oxidized by hydrogen peroxide and sodium hypochlorite as oxidizing agent. First, $25 \mathrm{~g}$ of flour were dispersed in specific amount of demineralized water in order to get the determined percentage of slurry which is varies $(10 \%, 20 \%$ and $30 \%$ ). Oxidation process were conducted at $30,35,40$, $45^{\circ} \mathrm{C}$ temperature with continues stirring and continues addition of oxidizing agent uptill the concentration of oxidizing agent were achieved (1\%,2\% and 3\%). After the oxidation process, the flour were washed using demineralized water up to four times to minimize the impurities, then filtered, and the cake were dried in $50^{\circ} \mathrm{C}$ for 12 hours followed by grinding up till the flour particle 100 mesh in size. Each sample is wrapped in small vacuum plastic bag and kept in temperature $28 \pm 2^{\circ} \mathrm{C}$ for further analysis.

\subsection{Swelling power and water solubility analysis}

Swelling power and solubility of flour were determined by the following methods. The method were conducted by heating a flour-water slurry $(0.1 \mathrm{~g}$ flour in $10 \mathrm{~mL}$ diminerilized water) in a reaction tube at $60 / \mathrm{C}$ for 30 min, with constant mixing (Ariyanti, 2013). The slurries were centrifuged at $1600 \times \mathrm{g}$ for $15 \mathrm{~min}$ in a Superspeed centrifuge (Sorvall@ RC-6, Kendro laboratory products, NC, USA). The supernatant were separated and swollen flour as cake were weighted for swelling power calculation. Meanwhile, $5 \mathrm{~mL}$ of supernatant were separated and dried as the left over in dried tube were weighted to get the percentage of water solubility value.

\section{Results and Discussions}

3.1. Effect of oxidation process parameter on swelling power and water solubility of modified taro flour

Hydroxyl radical $(\mathrm{HO} \bullet)$ from hydrogen peroxide commonly occur prior oxidation process, thus responsible to cut the bond of amylose molecules from complex starch molecules and released it to the system. As shown in Figure 1 and 2, for the first 30 minutes hydroxyl radical
(HO•) works effectively so we can see that there were a significant increase in swelling power and water solubility of the flour. Similar trend also found in corn starch oxidation (Wang and Wang, 2003) and Peruvian Carrot starch oxidation (Matsuguma, et al. 2009). It also been stated by Chan, et al. 2009 that amylose content in starch has some tendency to the reduction of swelling power, meanwhile the total amount of amylopectin contained in the starch act in the opposite.

Oxidation process lead to amylose chain depolymerization which reduce the degree of chrystalinity and allow water molecule to enter inside amylopectin chain as it can increase swelling power of the flour. Meanwhile, depolymerized amylose with shorter chain length begin to dissolve into water contained in system as it lead to the significant increase of water solubility properties of the flour.

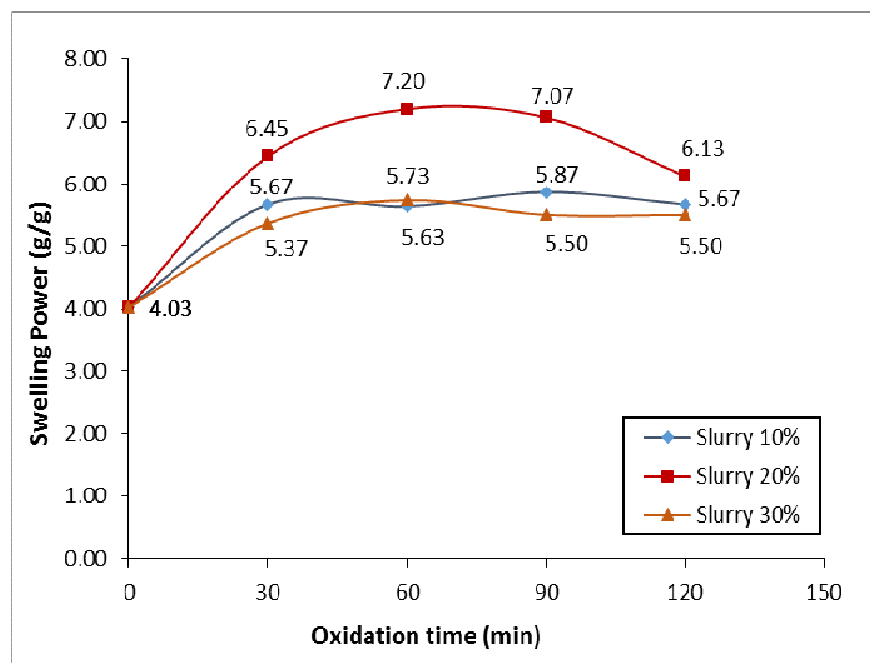

Figure 1. The effect of slurry concentration to swelling power of modified taro flour with $\mathrm{H}_{2} \mathrm{O}_{2}$ concentration $2 \%$, temperature $30^{\circ} \mathrm{C}$ in variation of oxidation time.

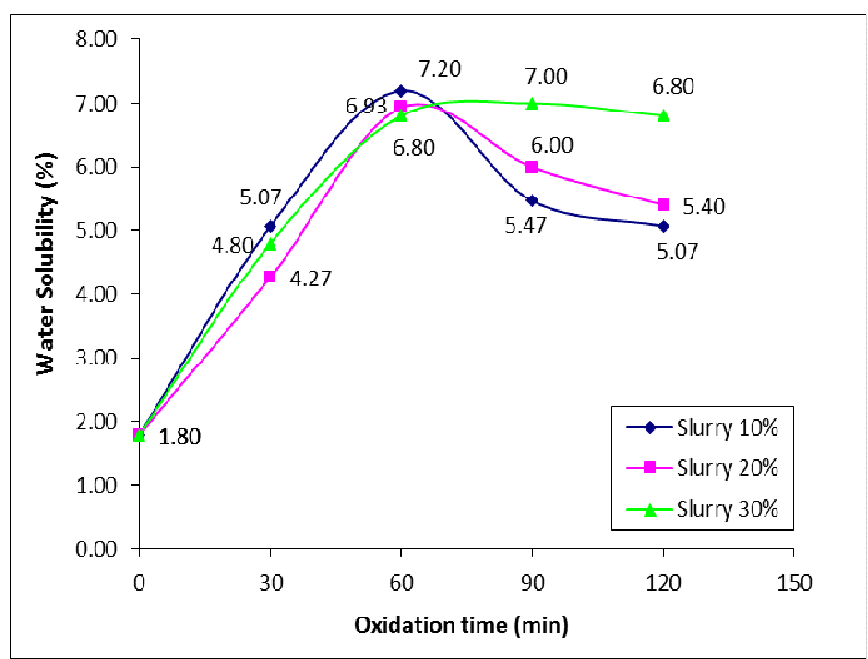

Figure 2. The effect of slurry concentration to water solubility value of modified taro flour with $\mathrm{H}_{2} \mathrm{O}_{2}$ concentration $2 \%$, temperature $30^{\circ} \mathrm{C}$ in variation of oxidation time. 


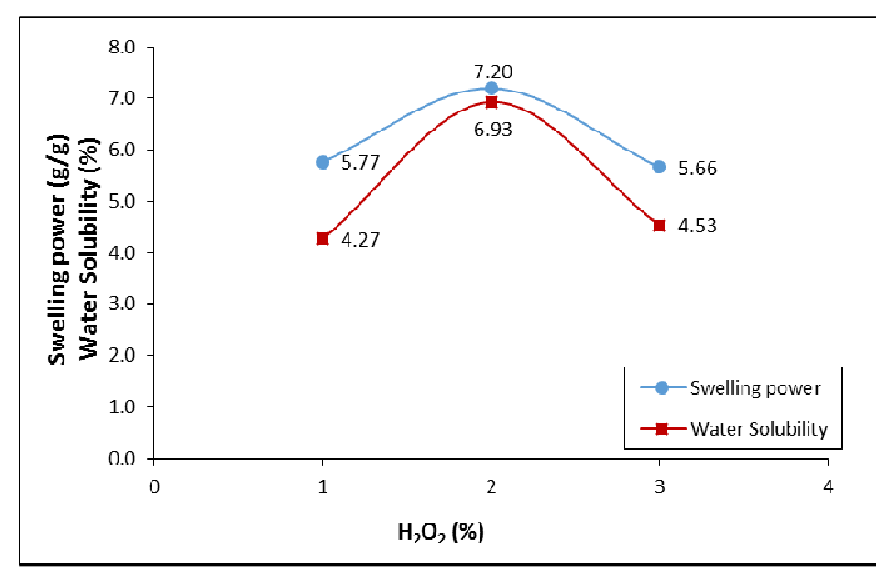

Figure 3. The effect of $\mathrm{H}_{2} \mathrm{O}_{2}$ concentration to swelling power and water solubility value of modified taro flour with slurry $20 \%$, temperature $30^{\circ} \mathrm{C}$ and 60 min operation time

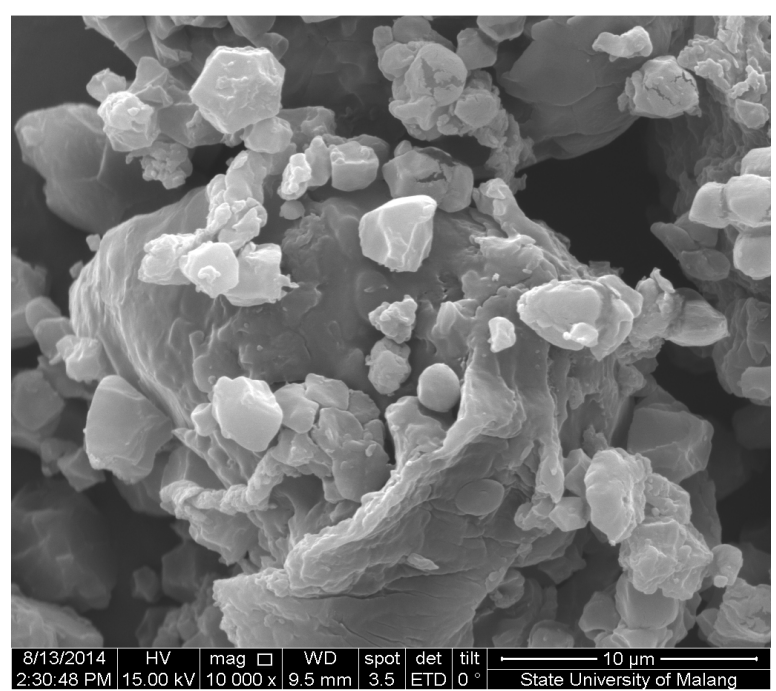

a

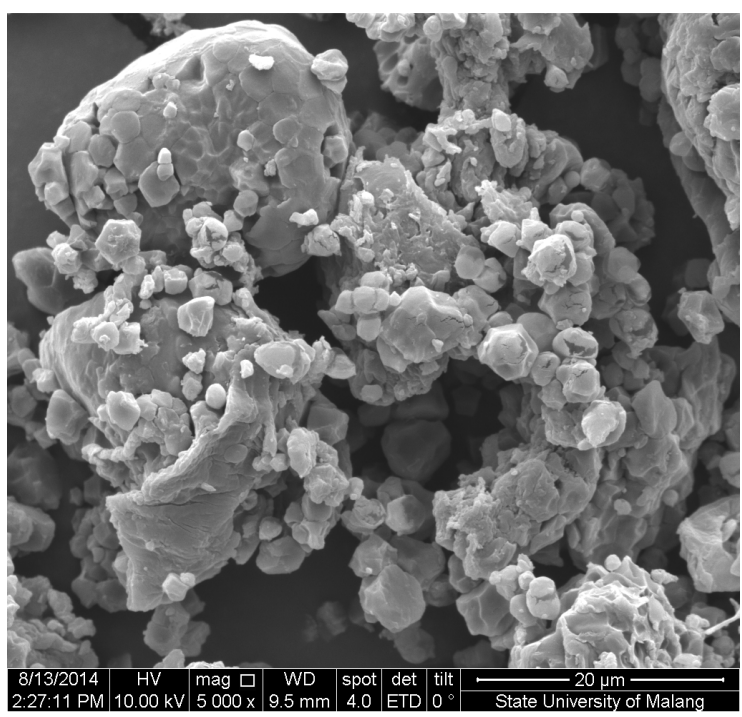

c

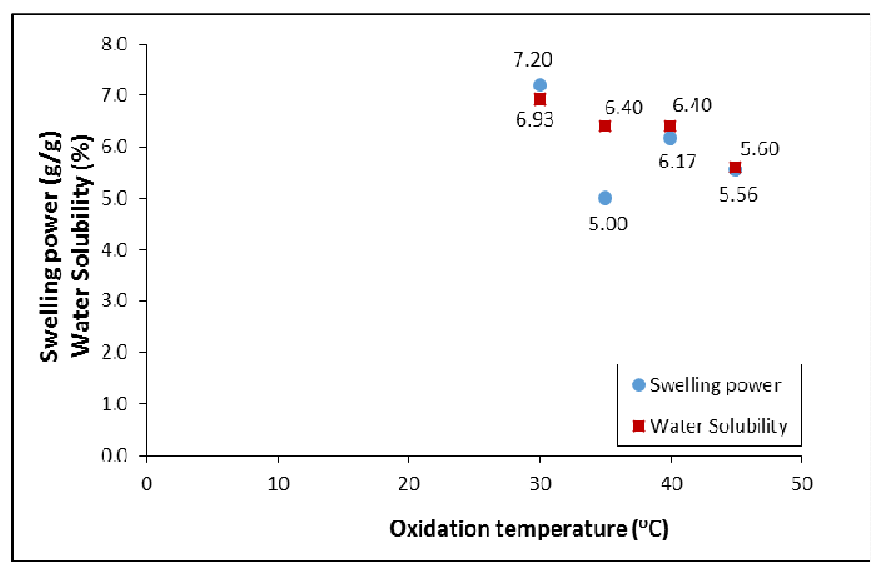

Figure 4. The effect of oxidation temperature to swelling power and water solubility value of modified taro flour with $\mathrm{H}_{2} \mathrm{O}_{2}$ concentration $2 \%$, slurry $20 \%$, temperature $30^{\circ} \mathrm{C}$ and 60 min operation time

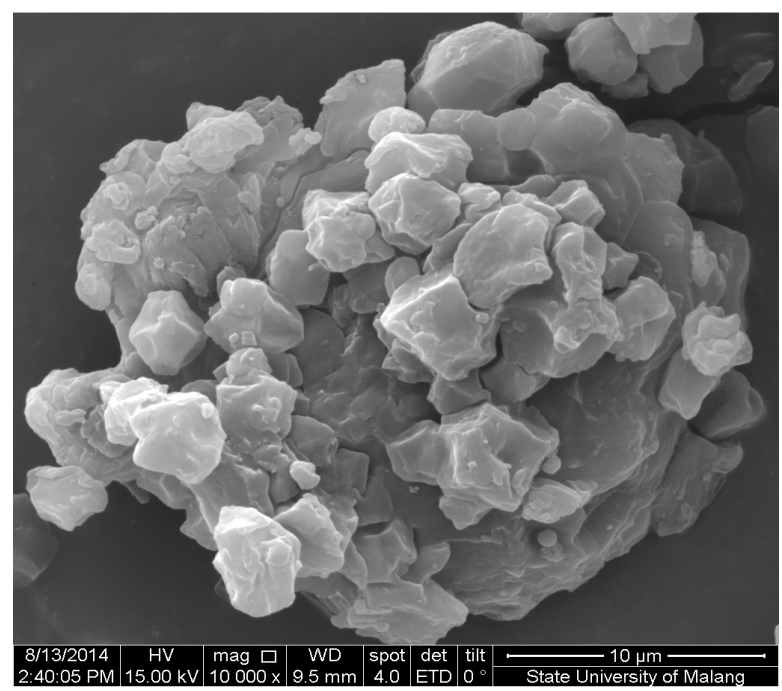

b

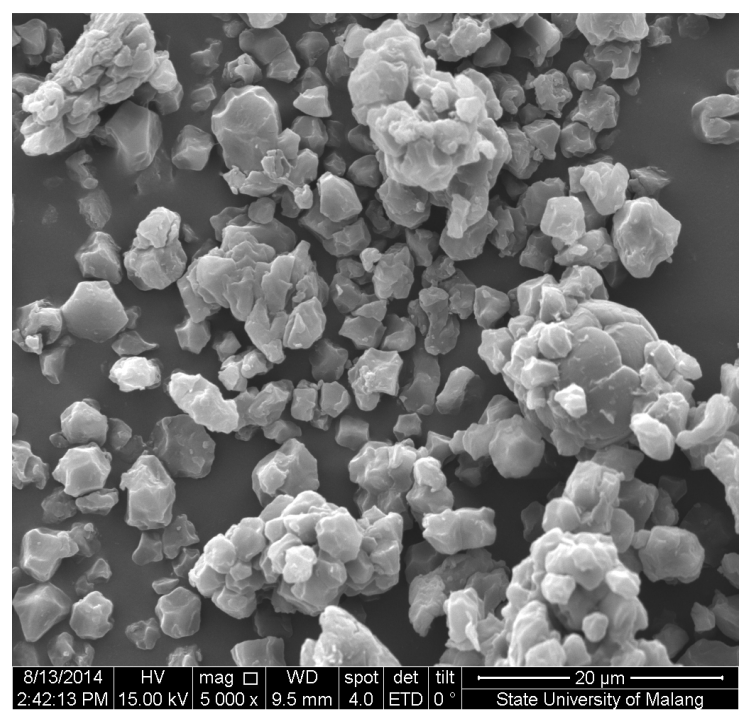

d

Figure 5. Scanning Electron Microscopy analysis on rheology of unmodified taro flour (a dan c); and modified taro flour by $\mathrm{H}_{2} \mathrm{O}_{2}$ oxidation (b dan d) 
As in Matsugama (2009), stated that water solubility properties of the flour were determined by amylose fraction released from starch chain.

Slurry ratio indicate starch contained (amylose and amylopectin) in flour solution which oxidized by the same amount of $\mathrm{H}_{2} \mathrm{O}_{2}$. Figure 1 shows that the highest swelling power value was obtained in $20 \%$ slurry ratio with $7.2 \mathrm{~g} / \mathrm{g}$ swelling power value in $60 \mathrm{~min}$ operation time, and it is higher than $10 \%$ and $30 \%$ slurry ratio which were found to be $5-6 \mathrm{~g} / \mathrm{g}$. In $10 \%$ slurry ratio, it has lower amylose content compared to $20 \%$ slurry ratio. As it is lower, in the same operation time, depolymerization occurred in the system continue to depolymerized amylopectin chain. The absence of some amount of amylopectin lead to small number of water molecule entering the chain and lowering the swelling power value of the flour (Lawal, 2004). The other case, in fact $30 \%$ slurry ratio has larger number of amylose and amylopectin, the swelling power was slightly lower than $20 \%$ slurry ratio. Partial depolymerization might occurred as the fact that $30 \%$ slurry ratio has larger number of amylose chain and by using the same amount of oxidizing agent concentration as it is used in 10 and $20 \%$ slurry ratio oxidation system, not all amylose chain were released into system and only small number of water molecule can access the amylopectin chain as it is blocked by remaining amylose.

Concentration of oxidation agent used in taro flour oxidation process was found to have effect on value of swelling power and water solubility as shown in figure 3 . In the same operation time, the used of concentration $\mathrm{H}_{2} \mathrm{O}_{2} 2 \%$ shows highest swelling power and water solubility. This condition state that there has to be an exact ratio between oxidizing agent and starch content in the system. The used of higher concentration of $\mathrm{H}_{2} \mathrm{O}_{2}$ (3\%) lead to continuous oxidation which convert the hydroxyl group of amylose and amylopectin in to carbonyl the carboxyl. This transformation cause the reduction of water molecule trapped in amylopectin chain which associate with the reduction of swelling power. Those small group also sensitive in the development of cross linking bond that block the water from amylopectin chain and stop the short chain amylose to dissolve (Wang \& Wang, 2003; Lawal, 2004; Chan, et.al., 2009; Tethool, et al., 2012; Ariyanti, 2013)..

Another process parameter is temperature. Temperature seems to have a negative effect on taro flour properties as shown in figure 4. Oxidation at ambient temperature seems to be the best choice as it result highest swelling power and water solubility properties, compared with higher temperature $\left(35,40,45^{\circ} \mathrm{C}\right)$ which tend to reducing the value of its properties and not feasible in technique and economic point of view.

The exalation of temperature can increase oxidizing agent $\mathrm{H}_{2} \mathrm{O}_{2}$ activity (Zhang et al. 2012). This upgraded activity can break through the chrystaline structure of amylose so that amylopectin can have a wide access to the water molecule contained in the system. However, oxidation process still continue to convert the hydroxyl group of amylose and amylopectin in to carbonyl the carboxyl group and only small amount of water can be absorb by the amylopectin chain (Kumoro, et al., 2010).

\subsection{Scanning Electron Microscopy analysis on flour rheology}

Surface analysis on taro flour rheology using scanning electron microscopy (SEM) can be found in figure 5. There were a significant changes in the surface of taro flour granule before and after modification via H2O2 oxidation process. Figure $5 \mathrm{a}$ and $\mathrm{c}$ shows the structure of taro granule before modification applied, it depict the large diameter of taro granule as it is compared to figure $5 b$ and $d$ which shows several parts of broken granule formed as particles with smaller diameter and even distribution on each particle.

\subsection{Modified taro flour application on consumable cake}

Organoleptic test also applied in unmodified and modified taro flour based consumable cake. The blind test was conducted by comparing modified taro flour based cake with wheat flour cake using several parameter which employ 20 independent respondent. The appearance of the cakes and average result of organoleptic test can be seen in figure 6 and Table 2. As in Matsugama (2009), stated that water solubility properties of the flour were determined by amylose fraction released from starch chain.

Slurry ratio indicate starch contained (amylose and amylopectin) in flour solution which oxidized by the same amount of $\mathrm{H} 2 \mathrm{O} 2$. Figure 1 shows that the highest swelling power value was obtained in $20 \%$ slurry ratio with $7.2 \mathrm{~g} / \mathrm{g}$ swelling power value in $60 \mathrm{~min}$ operation time, and it is higher than $10 \%$ and $30 \%$ slurry ratio which were found to be 5-6 g/g. In 10\% slurry ratio, it has lower amylose content compared to $20 \%$ slurry ratio. As it is lower, in the same operation time, depolymerization occurred in the system continue to depolymerized amylopectin chain. The absence of some amount of amylopectin lead to small number of water molecule entering the chain and lowering the swelling power value of the flour (Lawal, 2004). The other case, in fact $30 \%$ slurry ratio has larger number of amylose and amylopectin, the swelling power was slightly lower than $20 \%$ slurry ratio. Partial depolymerization might occurred as the fact that $30 \%$ slurry ratio has larger number of amylose chain and by using the same amount of oxidizing agent concentration as it is used in 10 and $20 \%$ slurry ratio oxidation system, not all amylose chain were released into system and only small number of water molecule can access the amylopectin chain as it is blocked by remaining amylose.

Concentration of oxidation agent used in taro flour oxidation process was found to have effect on value of swelling power and water solubility as shown in figure 3 . In the same operation time, the used of concentration $\mathrm{H}_{2} \mathrm{O}_{2} 2 \%$ shows highest swelling power and water solubility. This condition state that there has to be an exact ratio between oxidizing agent and starch content in the system. The used of higher concentration of $\mathrm{H}_{2} \mathrm{O}_{2}$ (3\%) lead to continuous oxidation which convert the hydroxyl group of amylose and amylopectin in to carbonyl the carboxyl. This transformation cause the reduction of water molecule trapped in amylopectin chain which associate with the reduction of swelling power. 


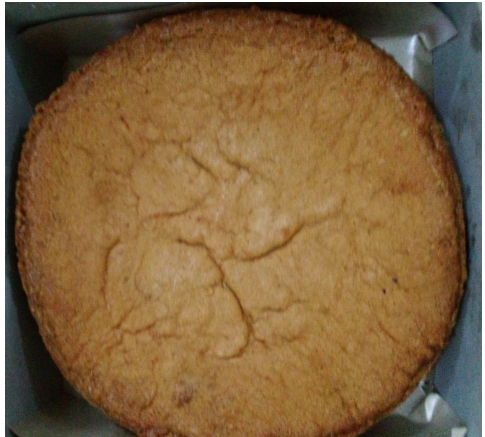

a

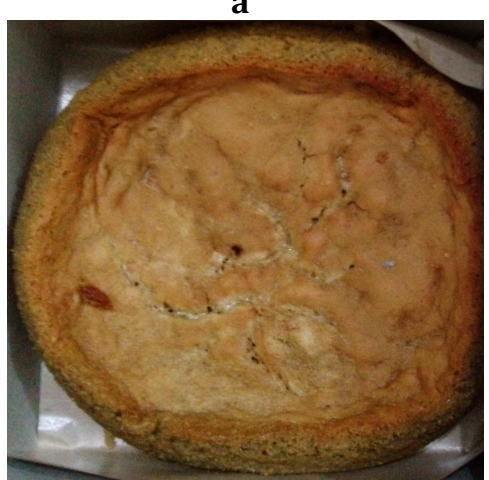

d

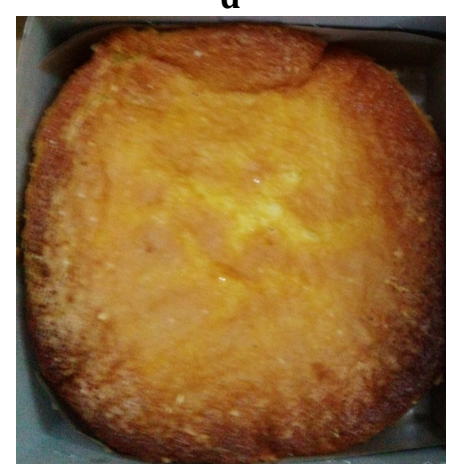

g

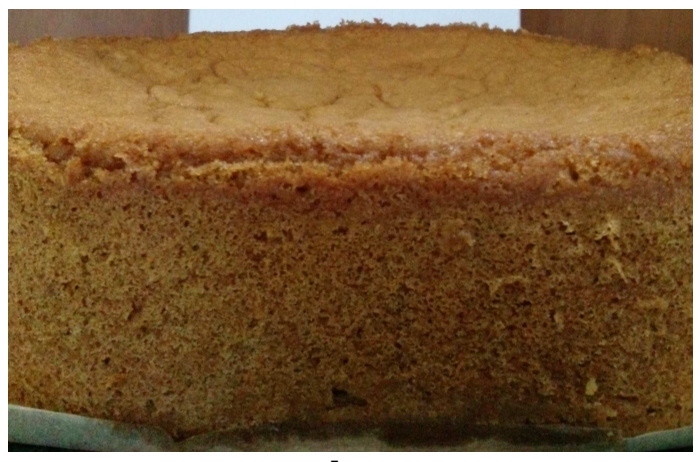

b

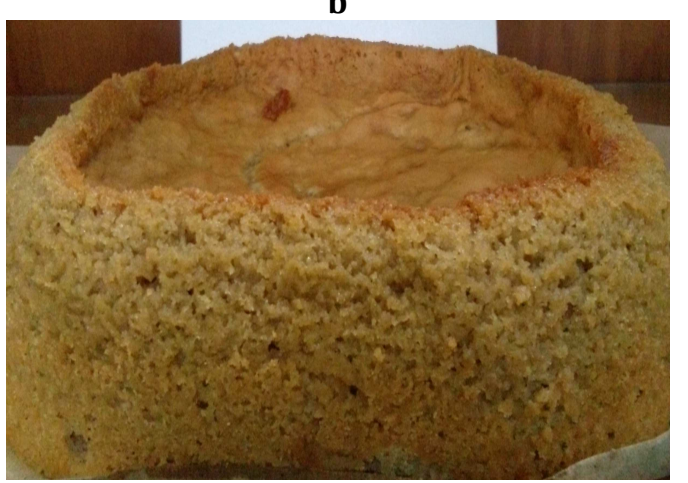

$\mathbf{e}$

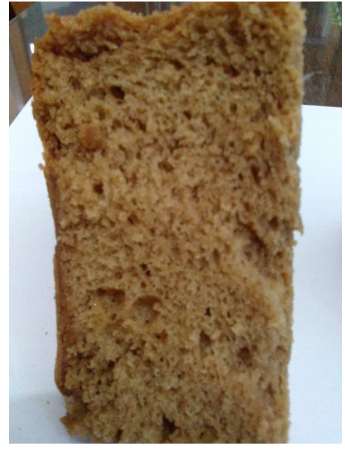

c

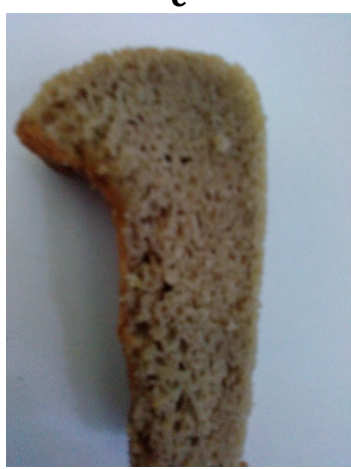

f

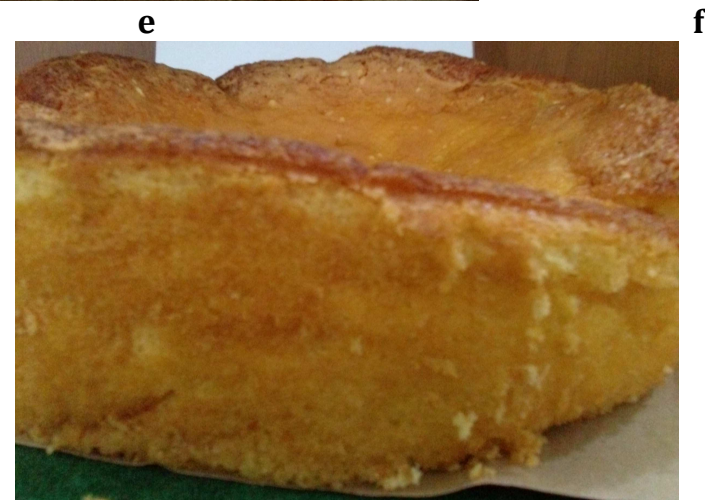

$\mathbf{h}$

Figure 6. $\mathrm{H}_{2} \mathrm{O}_{2}$ modified taro flour based cake (a. front; b side; c. slice form); unmodified taro flour based cake (c. front; $\mathrm{d}$ side; e. slice form); and wheat flour based cake ( $\mathrm{g}$. front; h side)

Those small group also sensitive in the development of cross linking bond that block the water from amylopectin chain and stop the short chain amylose to dissolve (Wang \& Wang, 2003; Lawal, 2004; Chan, et.al., 2009; Tethool, et al., 2012; Ariyanti, 2013).

Another process parameter is temperature. Temperature seems to have a negative effect on taro flour properties as shown in figure 4. Oxidation at ambient temperature seems to be the best choice as it result highest swelling power and water solubility properties, compared with higher temperature $\left(35,40,45^{\circ} \mathrm{C}\right)$ which tend to reducing the value of its properties and not feasible in technique and economic point of view.

The exalation of temperature can increase oxidizing agent $\mathrm{H}_{2} \mathrm{O}_{2}$ activity (Zhang et al., 2012). This upgraded activity can break through the chrystaline structure of amylose so that amylopectin can have a wide access to the water molecule contained in the system. However, oxidation process still continue to convert the hydroxyl group of amylose and amylopectin in to carbonyl the carboxyl group and only small amount of water can be absorb by the amylopectin chain (Kumoro, et al., 2010).

\subsection{Scanning Electron Microscopy analysis on flour rheology}

Surface analysis on taro flour rheology using scanning electron microscopy (SEM) can be found in figure 5 . There were a significant changes in the surface of taro flour granule before and after modification via H2O2 oxidation process. Figure $5 \mathrm{a}$ and c shows the structure of taro granule before modification applied, it depict the large diameter of taro granule as it is compared to figure $5 \mathrm{~b}$ and $\mathrm{d}$ which shows several parts of broken granule formed as particles with smaller diameter and even distribution on each particle.

\subsection{Modified taro flour application on consumable cake}

Organoleptic test also applied in unmodified and modified taro flour based consumable cake. The blind test 
was conducted by comparing modified taro flour based cake with wheat flour cake using several parameter which employ 20 independent respondent. The appearance of the cakes and average result of organoleptic test can be seen in figure 6 and Table 2.

Table 2. Organoleptic test of taro flour based consumable cake

\begin{tabular}{cccc}
\hline \multirow{2}{*}{ Parameter } & \multicolumn{3}{c}{ Flour } \\
\cline { 2 - 4 } & $\begin{array}{c}\mathbf{H}_{\mathbf{2}} \mathbf{O}_{2} \\
\text { modified } \\
\text { taro flour }\end{array}$ & $\begin{array}{c}\text { Unmodified } \\
\text { taro flour }\end{array}$ & $\begin{array}{c}\text { Wheat } \\
\text { four }\end{array}$ \\
\hline Texture & 4.0 & 2.8 & 4.1 \\
Flavors & 3.5 & 3.2 & 3.9 \\
Taste & 3.7 & 3.4 & 3.9 \\
Color & 3.8 & 2.8 & 4.3 \\
Total & 3.7 & 3.1 & 4.1 \\
\hline
\end{tabular}

Note: Score of organoleptic test: 5 = really good; $4=$ good; 3 =ordinary; 2 = not good; 1 = really not good

Wheat flour based cake was used as standard in texture, flavors, taste and color. As it has spongy and soft texture, great flavors and taste and gold bright yellowish color. Unmodified taro flour based cake has a pale brown color, somewhat musty aroma, the taste was ordinary, the texture is soft however it does not sponge compared to wheat flour based cake. Meanwhile the cake that made from modified taro flour has a brown color with aromas and flavors are pretty good, the texture also very spongy and soft as all properties in wheat flour based cake.

\section{Conclusions}

Taro flour oxidation by hydrogen peroxide was proven to have a positive effect on taro flour properties such as swelling power and water solubility. By using $20 \%$ slurry ratio, $2 \%$ of hydrogen peroxide concentration at $30^{\circ} \mathrm{C}$ temperature and in 60 min oxidation time, taro flour can reach its optimum properties with $7.2 \mathrm{~g} / \mathrm{g}$ swelling power and $6.93 \%$ water solubility as unmodified taro flour was noted to have $4.3 \mathrm{~g} / \mathrm{g}$ swelling power and $1.8 \%$ water solubility. This values are in the range of American wheat flour properties, which can be used as the evidence that taro flour can replace wheat flour in several application. In addition organoleptic test also prove that modified taro flour based cake can compete the wheat flour based cake assessed from texture, flavor, taste and color with only using 1/3 parts of flour compared to wheat flour.

\section{Acknowledgment}

This research was funded by Ministry of Education and Culture as part of Penerimaan Negara Bukan Pajak (PNBP) Universitas Diponegoro Year 2014, DIPA 023.04.2.189815/2014 dated 05 Desember 2013

\section{References}

Agama-Acevedo, E., Garcia-Suarez, F. J., Gutierrez-Meraz, F., SanchezRivera, M. M., Martin, E. S. And Bello-Pe' rez, L. A., (2011), Isolation and partial characterization of Mexican taro (Colocasia esculenta L.) starch, Starch, 63, 139-146.

Alam, F. dan Hasnain, A., (2009), Studies on Swelling and Solubility of Modified Starch from Taro (Colocasiaesculenta): Effect of $\mathrm{pH}$ and Temperature, Agriculturae Conspectus Scientificus, 74 (1), 45-50.

Ariyanti, D. \& Budiyati, C.S. (2013). Modifikasi tepung umbi talas bogor (Colocasia esculentum (I) schott) melalui proses oksidasi dengan $\mathrm{H}_{2} \mathrm{O}_{2}$ sebagai bahan pangan fungsional pengganti tepung terigu. SRKP 2014, UNDIP-Semarang.

Chan, H.T., Bhat, R., \& Karim, A.A., (2009), Physicochemical and Functional Properties of Ozone-Oxidized Starch. Journal of Agricultural and Food Chemistry, 57, 5965-5970. DOI:10.1021/jf9008789

Kumoro, A. C., Retnowati, D. S. And Budiyati, C. S., (2010), Microwave Assisted Synthesis and Characterization of Acetate Derivative Cassava Starch, American Journal of Food Technology, 5 (2), 100110.

Lawal, O. S., (2004), Composition, physicochemical properties and retrogradation characteristics of native, oxidized, acetylated and acid-thinned new cocoyam (Xanthosoma sagittifolium) starch. Food Chemistry, 87, 205-218.

Leach, H.W., Mc Cowen, L.D., and Schoch, T .J. (1959), Structure of the starch granules. In: swelling and solubility patterns of various starches, Cereal Chemistry, 36, 534 - 544.

Matsuguma, L.S., Lacerda, L.G., Schnitzler, E., da Silva Carvalho Filho, M.A., Franco, C.M.L and Demiate, I.M., (2009), Characterization of Native and Oxidized Starches of Two Varieties of Peruvian Carrot (Arracacia xanthorrhiza, B.) from Two Production Areas of Paraná State, Brazil. Brazilian Archives of Biology and Technology, Vol.52(3): 701-713.

Niba, L.L., (2003). Processing effects on susceptibility of starch to digestion in some dietary starch sources. International Journal of Food Sciences and Nutrition, 54, 97-109.

Tethool, E.F., (2012), Pengaruh Konsentrasi Hidrogen Peroksida dan Irradiasi Ultraviolet terhadap Sifat Fisikokimia dan Baking Expansion Pati Sagu, Prosiding InSINas 2012.

Wang, Y.J. \& Wang, L., (2003), Physicochemical properties of common and waxy corn starches oxidized by different levels of sodium hypochlorite. Carbohydrate Polymers, Vol. 52: 207-217. 